\title{
A Critical Review of Municipal Solid Waste Legislation and Compliance in Greece- In the Context of the EU Landfill Directive
}

\author{
Chukwunonye Ezeah ${ }^{\mathrm{a}}$, Timothy Byrne ${ }^{\mathrm{b}}$ \\ ${ }^{a}$ Faculty of Sciences and Engineering, University of Wolverhampton, City Campus-South, Wulfruna Street, \\ Wolverhampton, UK, WV1 $1 L Y$ \\ ${ }^{b}$ School of Sciences and Technology, The University of Northampton
}

\begin{abstract}
Greece has been a full member of the European Union since 1981. The country currently produces about 4.5 million tonnes of municipal and commercial waste annually, equivalent to a per capita waste generation rate of between 400/500 kilograms. Of the total amount of Municipal Solid Waste (MSW) generated in 2010, 80\% was landfilled contrary to the expectations of the EU landfill directives. In this respect, Greece was among the few EU countries that missed the target of diverting 75\% of 1995 levels of biodegradable waste from landfills. Since then, the country has continued to struggle in achieving the minimum targets of the Landfill Directive. This paper critically reviews MSW legislation and compliance in Greece, from the context of the EU Landfill Directive (1999/31/EC). The paper recommends drastic actions to reduce the amount of waste sent to landfill in Greece, if the EU Directive (1999/31/EC) target for 2020 of $35 \%$ were to be realised. The paper also recommends encouragement of greater participation in recycling by citizens to meet the $50 \%$ recycling target set by the Revised Waste Framework Directive (2008/98/EC).
\end{abstract}

Keywords: Municipal Solid Waste, Waste Legislation and compliance, EU Landfill Directive, Greece

\section{Introduction}

As a full member of the European Union since 1981, Greece has an obligation to comply with applicable EU legislations on waste management such as the Landfill Directive 1999/31/EC (1). The country currently produces about 4.5 million tonnes of domestic and commercial waste, equivalent to a per capita waste generation rate of 450 kilograms annually (2). Paradoxically, despite the current economic situation in Greece, waste generation has continued to increase year on year; this situation has been partly attributed to the influence of migration from EU ascension countries (3). Of the total amount of municipal solid waste (MSW) generated in Greece in 2010, 80\% was landfilled (4). Of this figure, approximately, 53\% was disposed of in thirty nine licensed engineered landfill sites which meet the minimum specification for sanitary landfill (5). The remaining 47\% was disposed of in 155 illegal dump sites (6). From the foregoing, it can be seen that Greece is at the moment, far from complying with the expectations of the EU Landfill Directive for developed member states (1999/31/EC) (1). As much as $81 \%$ of the MSW landfilled in Greece is biodegradable municipal waste. In specific terms, this waste stream comprises mainly of, food waste $39.7 \%$, paper $22 \%$ and other organics $10.5 \%$ (5). Notably, the EU Landfill Directive (1999/31/EC) sets out stringent targets for the reduction of biodegradable municipal waste sent to landfill in all EU member states (1). The legislation sets out target reductions in biodegradable municipal waste sent to landfill, benchmarked against corresponding volumes of biodegradable municipal waste sent to landfill in 1995 (1).

These targets are set as follows:

- $75 \%$ reduction of biodegradable municipal waste sent to landfill (by weight) five years after the directive came into force: 2006

- $50 \%$ reduction of biodegradable municipal waste sent to landfill (by weight) eight years after the directive came into force: 2009

- $35 \%$ reduction of biodegradable municipal waste sent to landfill (by weight) fifteen years after the directive came into force: 2016

In 2010, Greece amongst a few other EU countries missed the target of diverting 75\% of biodegradable waste from landfills $(1 ; 4)$. despite having been given a four year derogation by the European Commission to implement alternate waste treatment infrastructure. Since then, the country has struggled to achieve the minimum target of the Landfill Directive

\section{Waste Governance And Legal Context In Greece}

At the National Level, matters relating to waste management are administered by the Ministry of Physical Planning and Environment, who also produce waste policy goals usually reviewed every five years. 
The first attempt by Greece at producing a piece of national legislation on waste management was via the Sanitary Ordinance Eib/301/1964 (6). This piece of legislation related to the collection, transport and disposal of municipal wastes. That legislation was subsequently superseded by Law 1650/86 and further amended by Law $3010 / 02$. These revised pieces of legislation cover basic requirements for the collection and transport of waste as well as the curtailment of uncontrolled dumping sites (6).

Since the transposition of the Waste Framework Directive (WFD) 1991 (91/156/EEC) into Greek national legislation (7)., several acts have come into force in the country with significant impacts at both national and local government levels $(8 ; 6)$. Despite adopting the WFD into law, there has been much delay in adopting the waste hierarchy into Greek legislation so as to guide and underpin the implementation of national recycling programmes and diversion of biodegradable municipal waste from landfill $(7 ; 8 ; 6)$.

The initial failure of waste governance in Greece has been traced to the Central Government's inability to provide required national waste management plans and targets. This situation left various Prefectures (County Councils) with added planning responsibilities in addition to their primary responsibility of producing regional waste management reports which are required to be reviewed every five years $(9 ; 6)$. The plans must include predicted waste production, a Greek variant of Waste Data Flow in the UK (10), the expected recovery of waste for recycling and addressing the use of facilities i.e. existing landfills as well as future plans for either the opening of a new landfill or alternate treatment infrastructure $(6 ; 9)$. It is also required that the Prefectures share plans and proposals for waste reduction with the Local Authorities i.e. district and borough councils (Waste Collection Authorities) within forty five days for their comments before they are published (6).The responsibilities of Prefectures also include liaising with The Ministry for the Environment for consented permits for waste handling, collection, waste transfer as well as the permits for the operation of waste treatment facilities by municipal associations or unitary authorities $(6,9)$. In this regard, the main interest of Prefectures is usually to ensure that the Waste Collection Authorities and Unitary Authorities are competent in managing a sustainable waste collection and transfer system. The Prefecture also ensures that both the municipal organisations and unitary authorities are competent in treating and disposing of waste in the most sustainable way (11).

When new landfills are proposed for construction, the Ministry of the Environment is duty bound to carry out an Environmental Impact Assessment (EIA) to assess the suitability of the proposed site $(11 ; 9)$. If the Ministry of the Environment considered the site suitable for use as a landfill, they are also responsible for the issue of a site licence and environmental permit for the processing and treatment of biodegradable municipal waste (11; 9).Various Ministerial Decisions have been produced to set technical standards for future design, operation and maintenance of landfill sites as well as the introduction of recycling programmes to reduce the volumes of biodegradable waste being sent to landfill (6).

\section{Municipal Waste Management In Greece In The Context Of European Law}

General waste legislation considerations

Creditably, Greece has been able to transpose existing EU directives on waste management into national legislations:

1) The first two pieces of EU legislation with regards to waste management were: Waste Framework Directive (75/442/EEC), superseded by the revised Waste Framework Directive (91/156/EEC) $(7 ; 12)$. Transposition of these Directives into Greek law encountered initial oppositions in Greece as a result of political considerations. However, the Revised Waste Framework Directive (2008/98/EC) was eventually transposed into Greek national legislation through Law 4042/2012 in 2012 (4).

2) EU Landfill Directive (1999/31/EC) was transposed into national legislation on the 16th December 2002 (1). This law sets three target dates to divert biodegradable municipal waste from landfill including the four year derogation i.e. $75 \%$ by $2010,50 \%$ by 2013 and $35 \%$ by 2020 benchmarked against waste produced in 1995 (5).

3) Waste Incineration Directive (2000/76/EC) was transposed into Greek national legislation in 2005 (13; 5).

4) Packaging Waste Directive (94/62/EC) as amended by Packaging Waste Directive (2004/12/EC) was transposed into law in 2007 (14). This directive states that member states had until the $31^{\text {st }}$ December 2011 to achieve a packaging recycling rate of $55 \%$ and $80 \%$ by weight or packaging waste to be diverted from landfill and recycled. Alternatively, member states had until the $31^{\text {st }}$ December 2011 , to divert $60 \%$ of packaging waste for recovery, for example, through energy recovery.

5) End of Life Vehicle Directive (ELV) (2000/53/EC) was transposed into Greek national legislation in 2007 $(14 ; 5)$. This directive targets to achieve the reuse or recovery of value from a minimum of $85 \%$ of vehicles destined for scrap. An increase of $95 \%$ reuse or recovery is required by the ELV Directive (2000/53/EC) by $2015(14 ; 5)$.

6) In line with the EU Landfill Directive (1999/31/EC) Greece also set stringent national targets in 2004 for the recovery of value from End of Life Tyres (ELT) so as to meet up with the bans imposed by the EU Landfill Directive (1) on whole tyres being sent to landfills in 2003 (15). 
7) Greece had also transposed into law, the reuse and recycling of construction and demolition waste in accordance with the WFD (91/156/EEC) (12) on the 22nd December 2003. The WFD (91/156/EEC) sets targets for the re-use and recycling of construction and demolition waste as follows: $30 \%$ by weight in $2012,50 \%$ by weight in 2015 , and $70 \%$ by weight in 2020 (12).

\section{Hazardous waste legislation in the context of European legal framework}

1) The management of Hazardous waste has also been transposed into Greek national government policy. This has been done largely in response to the requirements of the Waste Framework Directive (91/156/EEC) (12) as well as the Hazardous Waste Directive (1991/689/EEC) (16). Both pieces of legislations i.e. The Waste Framework Directive (1991/156/EEC) and the Hazardous Waste Directive (1991/689/EEC) were transposed into law on the $2^{\text {nd }}$ March 2007 and $28^{\text {th }}$ March 2006 respectively (16).

The Hazardous Waste Directive (1991/689/EEC) also covers the European Waste Shipment Regulations (1013/2006) on the shipments of hazardous waste from a developed member state to a developing member state (17). This legislation has also been mirrored by the Transfrontier Waste Shipment Regulations 2007 (18) following the introduction of Directives (86/279/EEC) and superseded by Directive (1013/2006) as issued by the European Union in 1986 and 2007 in respect to 'controlling the movements of waste within the European Union and regulating the movement of hazardous wastes' $(18 ; 19)$. This Directive is similar in context to the European Waste Shipment Regulations (1013/2006) in relation to monitoring both the import and export of wastes in particular those of hazardous nature, throughout the European Union $(17 ; 18)$. Both the directives of (86/279/EEC) and (1013/2006) have been transposed into Greek National Law (20).

2) The Waste Electronic and Electrical Equipment Directive (WEEE) (2002/96/EC) was transposed into Greek legislation on the $5^{\text {th }}$ March 2004 (21; 5). The WEEE Directive sets EU Member States a target of 65\% by weight of Waste Electrical and Electronic Equipment (WEEE) to be made available for sale on the market of each EU Member State in the three preceding years. The initial target year is $2016(21 ; 5)$. Recovery targets have been set by the Directive as follows: $31^{\text {st }}$ December 2011 for cooling equipment and large WEEE, $85 \%$ recovery and $80 \%$ prepare for reuse targets as well as the recycling of WEEE have been set. For TV screens and computer monitors, an $80 \%$ recovery rate has been set while a preparation and prepare for reuse rate has been set at $70 \%(21 ; 5)$. Targets for the recycling of fluorescent tubes (lighting equipment) as well as small (WEEE) has been set at $55 \%$. Finally, for gas lamps a rate of $85 \%$ has been set for reuse and recycling $(21 ; 5)$. These figures do not include the recast of the WEEE Directive whereby, the weight based target has now been modified to a collection based target with statutory dates set for 2019 (22)

3) The Battery Directive (2006/66/EC) has also been transposed into Greek national legislation . Greece transposed the battery directive into National Law on the $11^{\text {th }}$ October $2010(23 ; 5)$. The Battery Directive (2006/66/EC) sets targets for EU Member States to achieve a 25\% collection rate for small batteries (portable) by September 2012. This must increase to $45 \%$ by September 2016. To define efficiency in the collection of small portable batteries $65 \%$ of lead acid batteries, $75 \%$ of nickel - cadmium batteries and $50 \%$ or other waste batteries must be collected by the $26^{\text {th }}$ September 2011.

\section{Medical waste legislation in the context of European Legal Framework}

Greece has already transposed Directives (2000/76/EC) regarding the incineration of waste and the Revised Waste Framework Directive (2008/98/EC) into their national legislation (23; 5). In articles 17 and 20 of Directive (2008/98/EC), it states that, 'clinical wastes must be labelled, the correct records of their production as well as their carriage i.e. transportation because medical waste is classified as a 'Directive' waste, the monitoring and control through an audited paper-work trail (waste transfer note), from producer, to consignee to the end destination (treatment plant or recovery plant) must be carried out (24). The Directive (2008/98/EC) also states that the mixing of hazardous wastes for end treatment / disposal is banned to minimise risks to environmental health. The permitting of facilities which may have fallen under a former exemption will be regulated under the Integrated Pollution and Prevention Control (IPPC) Directive (25). Because these facilities are processing or recovering hazardous wastes, they will have to be monitored as a part (A1) installation by the Environmental Protection Agency of Greece (EPANET, 2010). Facilities which are permitted for dealing with non-hazardous wastes maybe restricted in accepting hazardous wastes under their (IPPC) permit $(24 ; 25)$. The co -disposal of hazardous wastes with non-hazardous in controlled or sanitary landfills are also banned under Directive (1999/31/EC) (1).

The Waste Framework Directive (2008/98/EC) also require hazardous wastes to be classified under Annex III of the Directive as per the guidance of the hazardous wastes list (HWC) under Directive (2000/532/EC) (26) and the European Waste Catalogue (2001/573/EC) (27). Through the guidance of the hazardous waste list (HWL) and the European Waste Catalogue (2001/573/EC), it will help member states to classify both hazardous and non-hazardous wastes. This will be based on a system whereby, the correct classification and labelling of dangerous substances and preparations are achieved as per the requirements under 
articles 17 and 20 of the Revised Waste Framework Directive (2008/98/EC) (24)

\section{Challenges militating against compliance with the European Landfill Directive Targets}

Although Greece has transposed the EU Landfill Directive (1999/31/EC) into its national legislation, little seems to have been done to either properly implement the directive, or meet any of its statutory targets ( 1 ; 4; 6). Dumping sites are still in operation (see Fig. 1), which are having detrimental effect on water pollution, as well as air pollution and forest fires (6). These environmental effects are a breach of the Groundwater Directive (80/68/EEC) which covers the effects of groundwater from potentially polluting substances $(6 ; 23)$. This also breaches provisions of the Water Framework Directive. No Environmental Impact Assessment (EIA) has been carried out at these sites either, and even if they had been, they would not meet any criteria laid down in the EIA Directive (25). The release of methane caused by the decomposition of the waste as well as waste spontaneously combusting and causing forest fires is a total breach of a site licence and Integrated Pollution Prevention and Control (IPPC) permit $(12 ; 25)$.

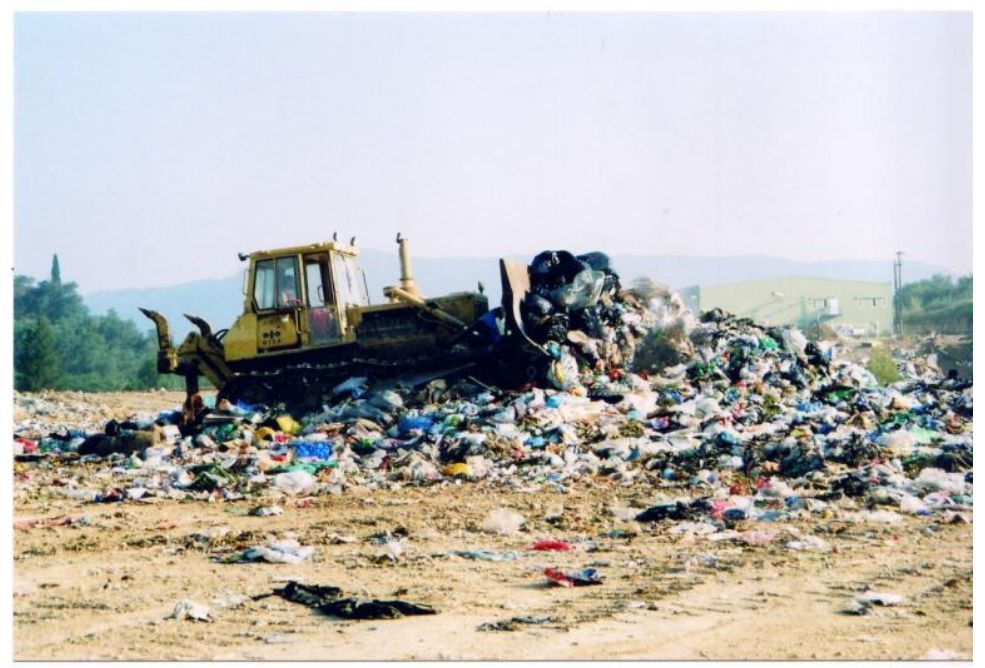

Fig 1: A bulldozer compacting municipal waste freshly delivered to the sanitary landfill site of Temploni on the island of Corfu. In the distance; the new Materials Recycling Facility (MRF) for processing commingled recyclables can also been seen (Author's photo)

Greek classification of dumping sites do not always mean depositing waste on land (6). Biodegradable municipal waste has been disposed of by tipping it off cliffs, on banks of torrents, rivers, stream beds, the coast, in springs where the water is used for human consumption further downstream, abandoned quarries, forested areas and archaeological areas. Because of this, there has been serious concern on the environmental impact these dumping sites have on Greece both as a nation as well as on tourism (6). Environmental effects to ground and surface water, soil, air and noise pollution have all been highlighted. The impact on both residents and tourists in relation to the uncontrolled deposition of waste on land has been also cause for concern, both in terms of the detrimental impacts it can have on human health as well as the long term consequential environmental effects associated with these illegal dumping activities (6). Furthermore, none of the existing dump sites could be upgraded to meet the requirements of a controlled or sanitary landfill site under the EU Landfill Directive (1999/31/EC) because of these existing sites do not fulfil the requirements of the Groundwater Directive and Environmental Impact Assessment of an Integrated Pollution Prevention and Control (IPPC) permit (6, 1, 25, 29,30).

In addition to this, the dumping of waste at sea is also banned under the Marpol Convention which was an international piece of legislation introduced in 1978 to prevent the dumping of wastes at sea (31). Greece transposed this piece of legislation into its national legislation in 1978 and fined various polluters; both ships and fixed installations on land over the periods 1981 to 2001 for causing ecological pollution and potential harm to marine life. The main emphasis is to maintain the water bodies around Greece and to prevent any pollution both from ships and from pollutants i.e. ships and inland installations entering into the sea, causing localised pollution (31). Notwithstanding this, Greece continues to use the sea as well as torrents, rivers, stream beds, the coast and springs to deposit 'Directive' waste, despite the danger of leachates produced by the decomposition of these wastes flowing in these watercourses and entering into the sea (6). This situation posses great danger to the tourist industry in Greece because none of the beaches would be able to maintain a 'blue flag' status and the sea would be unsafe for tourists to swim in apart from the harm to local marine life . 
Having said that, it must be noted that though Greek Local Authorities (Waste Collection Authorities) who deliver these wastes to the dumping sites know that such practices are not sustainable, there is no other alternative facility and to maintain a waste collection service for their citizens, they have no choice but to continue using these dumping sites, not minding their noncompliance with applicable EU legislation (Landfill Directive). On the long run these activities are continually ruining the environment around them and no enforcement action has been taken by the Ministry of Environment or government at both national and local level to cease operations of these facilities (6).

Another major factor as to why Greece continues to send a significant proportion of its waste to dumpsites is because it is an easy and cheap solution (6). There is no landfill tax levy as compared with other EU states such as the UK, where the local councils pay for the cost based on the weight of the waste (32). Since the cost of implementing alternative waste infrastructure to divert biodegradable municipal waste from landfill could be considerable, local politicians may be unwilling to bear it since they know that the investment in alternate waste infrastructure would result in a considerable cost which would need to be passed onto local tax payers (6).

The Prefecture and Regional governments are sometimes also not very concerned about the use of dumping sites, because they are not their responsibility. They take the stance that the responsibility is down to the local authorities (Waste Collection Authorities) if they choose to use them, as a result, the Prefecture and Regional government most often take no action with regards either to the operation or the environmental effects created by these facilities (6).

Apart from already highlighted issues, other political factors come into consideration too, if a sustainable municipal solid waste management system (MSWM) were to be implemented, considerable time would be required to study the suitability of a site through an EIA report (30), and to consider other factors such as its hydrogeology, site construction, environmental permitting, regulation under the Integrated Pollution and Prevention Control (IPPC) directive as well as mobilising site operation $(6 ; 25)$. The Prefecture and Regional government as well as the Ministry of the Environment would have to monitor and regulate the new facility, which could involve more government intervention, if the site was not managed in accordance with the requirements of the EU Landfill Directive (1999/31/EC) or its IPPC permit $(9 ; 1 ; 25)$. Therefore, it would demonstrate that all of the investment to construct a new controlled or sanitary landfill was not providing a sustainable waste management system for its citizens (6).

Having said this, local authorities are trying to make minimal improvements to their dumping sites, in order to prevent adverse environmental impacts and complaints from the host communities (6). Measures put in place include fencing, the placement of cover material on top of the waste to reduce the risk of fire and the waste being blown from the dumping site as well as fire protection. However, these measures are insufficient in helping the surrounding environment resolve long term problems associated with implementing a sustainable municipal waste management system. Where municipalities have used dumping sites to their full potential, the sites have merely been abandoned and nothing has been done to remediate the site and improve aesthetics so as to fit with its surroundings (6). The monitoring of the effects of the discharged leachate, methane management, analysis of surface water, the capping of the site as well as general long term monitoring of the environmental impacts associated with using this area as a dumping site $(6,29,12,25,30)$

Lately, Greece was referred to the Court of Justice for failing to clean up former dumping sites found abandoned on the island of Crete in the municipalities of Kouroupitos and Messomouri (6). In the year 2000, Greece was fined 2000 Euros by the Court of Justice for operation of illegal dumping site in Kouroupitos. Further action was taken in 2005 by the Court of Justice because of the continual operation of illegal dumping sites. Following on from the case, Greek authorities admitted that there were about 1,125 illegal dumping sites still in operation. However, it must be stated that this represents considerable reduction of dumpsites from an initial figure this number had diminished from 3,500 to 1,450 in the year 2002 (6).

Development and Operation of Sanitary landfill sites in Greece

The first sanitary landfills in Greece were constructed around the early 1990's. (34), by 1999, this number had grown to 43 sanitary landfills constructed to comply with the EU Landfill Directive (1999/31/EC). These landfills served $55 \%$ of the population $(6 ; 1)$. Based on 2010 figures, over 72 sanitary landfills are now in operation in Greece with an additional 16 sanitary landfills under construction (5). Construction of most of these sanitary landfills meet the requirements of the landfill directive (1999/31/EC) with liners 1mm thick made from bentonite as per the requirements for non- hazardous landfills and the effective capturing of methane using a flaretorch. Leachate treatment plants have also been constructed to manage the levels of Biochemical Oxygen Demand (BOD), Chemical Oxygen Demand (COD), ammonia and nitrogen present in leachates (1). 


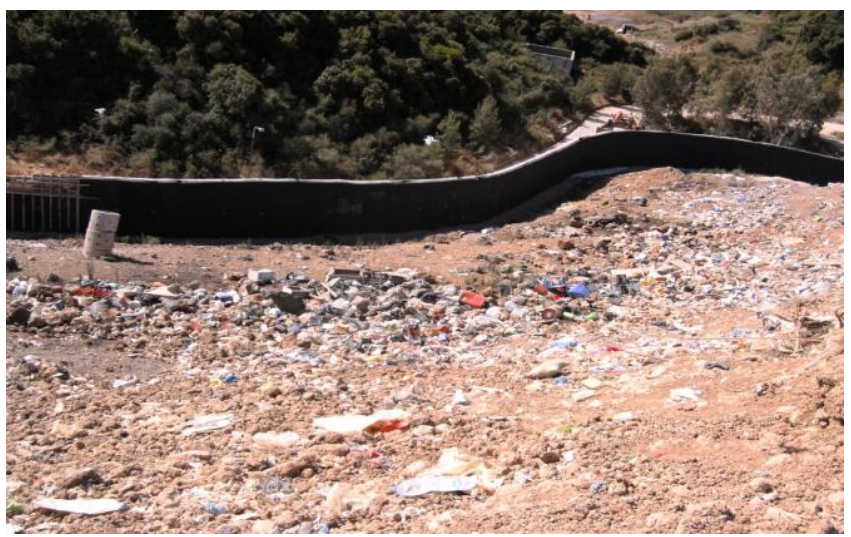

Figure 2: Shows the retainer wall of the sanitary landfill site of Temploni on the island of Corfu. Picture shows evidence of illegal deposition of WEEE in landfills (Author's photo).

The largest operational sanitary landfill site in Greece is in Ano Liosia Fyli- Athens. This landfill site serves $93 \%$ percent of the local population and receives waste from 70 municipalities $(6 ; 35)$ while in Thessaloniki, the former Tagaredes sanitary landfill used to serve $71 \%$ of the population and treated waste from 23 municipalities. The Tagaredes sanitary landfill site closed in early 2008 after reaching its designed capacity (34).

Notwithstanding the commendable steps taken towards increasing the number of sanitary landfills, there are increasing cases of noncompliance of the new sanitary landfill sites and breaching of the Integrated Pollution and Prevention Control (IPPC) permit $(6 ; 25)$. An example is the case of Ano Liosia - Fyli landfill in Athens. The site had compromised its environmental permit resulting in serious environmental impacts and complaints by local residents. These kinds of failings lead to immense public opposition for the construction of sanitary landfills in their local area.

\section{The Future of Waste Legislation Compliance in Greece}

From the foregoing, drastic action to reduce the amount of waste sent to landfill is urgently required in Greece, if the EU Directive (1999/31/EC) target for 2020 of 35\% were to be realised. A second but equally important challenge before the country is that having transposed the Revised Waste Framework Directive (2008/98/EC) into its national legislation, there is now an urgent need to commence implementation measures which places the new waste hierarchy model, with waste prevention and preparation for reuse at the top, followed by recycling, energy recovery from incineration lower down and the landfilling of waste as the least favoured and final solution, at the bottom of the waste hierarchy (24). The Revised Waste Framework Directive (2008/98/EC) also sets targets for all EU member states to comply by 2015 i.e. to source segregate five streams of dry recyclables from both domestic and commercial premises (24). The Waste Framework Directive (2008/98/EC) also sets recycling targets to be achieved: $45 \%$ by 2015 and $50 \%$ by 2020 . Greece will need to give attention to these drivers if a radical change in current waste management practices in the country were to change in a positive direction.

Until now, Greece has tried to manage the diversion of biodegradable municipal waste from sanitary landfills in two ways; the construction of mechanical biological treatment plants (MBT) where recyclables can be extracted from the municipal waste at the front end of the process (4) and the production of compost like output (CLO) at the back end. Currently there are five MBT plants operational in Greece: Ano Liosia which has a capacity of 300, 000 tonnes of municipal solid waste (MSW) per annum (36). The plant also extracts 201, 000 tonnes of organic waste from the overall waste throughput. The second facility has been built in Chania - island of Crete, having an annual throughput of 70,000 tonnes of MSW, while extracting 53, 600 tonnes of organic waste. The facility began operations in 2005 (37). The third facility has been built at Kalamata with an annual MSW processing capacity of 32, 000 tonnes and an annual organic extraction rate of 21,440 tonnes. This facility commenced operations in 1997. The latter two facilities use the traditional MBT process at the front end to extract dry recyclables, but the biodegradable fraction is treated in a bio drying process (36).

Seven other MBT plants are planned to be built, one in Hmathia which will have a MSW throughput of 70,000 tonnes per annum and will be able to recover 46,900 tonnes of organic fraction. Construction of this facility is being funded through a Private Finance Initiative (PFI) programme. A second plant is scheduled to be built at Ahaia which will have an annual MSW throughput of 120,000 tonnes per annum and able to recover an organic fraction of 80,400 tonnes. The plant will be a standard MBT process recovering the recyclables at the front end of the process, while the organic fraction will be landfilled (36). The plant is being funded through the EU Cohesion fund at a value of 55 million Euros. Other plants scheduled for construction in the near future are 
at Thessaloniki which will have a capacity to treat 450,000 tonnes of waste per annum, and recovering 301,500 tonnes of organic fraction; four plants are also proposed for, Ano Liosia - Fyli and Athens (capability of processing 80,000 tonnes of MSW with organic recovery of 53,600 tonnes). The exact date of the construction of this facility has not yet been determined, but the MBT technology predicted to be used at the facility, is source separated recyclables at the front end of the process, utilising either composting or AD for the organic fraction.Currently the Ano Liosia MBT plant in Athens is one of the largest in Europe, processing 300, 000 tonnes of MSW per annum. The plant extracts dry recyclables, refuse derived fuel (RDF) as well as a CLO (36). There are no markets for the RDF or CLO output at the present time, and therefore the RDF and CLO is used for landfill restoration purposes.

To also comply with targets set by the Revised Waste Framework Directive (2008/98/EC) and the transposition of the Packaging and Packaging Waste Directive (2004/12/EC) into Greek national law (24), Greece has implemented the collection of commingled recyclables in conjunction with a system known as the 'Collective Packaging Managing System' (CAMS-RECYCLING). This programme which commenced with full support by the Ministry of Environment has received wide acclaim (4). The collection of commingled recyclables was initially driven by the 'Hellenic Recovery and Recycling Corporation' (HERRCO S.A.), a not for profit organisation (38). CAMS-RECYCLING is constructing materials recycling facilities (MRF'S) across the whole of Greece for source segregating packaging waste and paper and cardboard. There are now fifteen MRF'S in operation across Greece (36).

Since many of the recycling schemes were rolled out in 2005 , there has been a gradual increase in the collection of commingled recyclables, with a major increase between 2006 and 2007 (15). In 2008, it was estimated that recycling / packaging waste collected accounted for 1,050,000 tonnes since the introduction of the recycling schemes (36). The collection of commingled recyclables after 2008 generally stabilised to between 17$18 \%$ of overall waste collected by municipalities. It is believed that despite Greece adopting the Waste Framework Directive (2008/98/EC) into their national legislation, current recycling rates are in the region of 25 $-33 \%(4 ; 24)$. At the current rate, it is doubtful if Greece will be able to meet the 50\% recycling target by 2020.

\section{Conclusions}

Despite the current economic situation in Greece, significant investment has been made towards sustainable waste management in the recent past. Notwithstanding this, greater investment is required to enable the country meet EU Landfill Diversion targets (1999/31/EC) by the year 2020 (1). In the interim, while the economic situation improves, Greece could consider imposing some kind of tax on waste taken to landfill. This could be implemented similar to the UK, where an annual landfill tax escalator has been in place since the 1996 (39). This has helped the UK in conjunction with Directive (1999/31/EC) construct alternative waste treatment infrastructure, for example, energy from waste and MBT plants to divert biodegradable and commercial waste away from landfill $(39 ; 1)$.

Another fiscal driver which could be introduced is the Landfill Allowance Trading Scheme (LATS). In the UK, this instrument had been found to be very effective. Legal backing for the instrument was introduced by central government in 2003, and allowances to Waste Disposal and Unitary Authorities across the UK for diverting biodegradable municipal waste from landfill were allocated thereafter. Waste Disposal Authorities and Unitary Authorities which had already implemented alternate waste treatment infrastructure, for example, waste to energy plants or MBT plants were not so reliant on using the allowances. Waste Disposal Authorities and Unitary Authorities who were still heavily reliant on using landfill because of possible planning and funding issues to implement alternate waste infrastructure would use all of their allowances before the end of the LATS financial trading year (40). Waste Disposal Authorities and Unitary Authorities who have already used their LATS allocation can trade allowances with other Waste Disposal Authorities and Unitary Authorities where they have alternate waste treatment infrastructure in place to treat biodegradable municipal waste. The trading sets penalties of one hundred and fifty pounds a tonne for Waste Disposal Authorities and Unitary Authorities that have already used their LATS allocation. Although this piece of legislation may seem complicated, it was successful as a fiscal driver in the UK in achieving landfill diversion (41). The LATS in England was abolished in 2013 at the end of the LATS financial trading year (42). A simple mechanism like LATS could be introduced by the central government of Greece to help to achieve reductions in the quantities of biodegradable municipal waste being sent to landfill, and help meet their legal obligations under (Directive 1999/31/EC).

\section{References}

[1]. Eur - lex. europe.eu (1999) Council Directive 1999/31/EC of 26th April 1999 on the landfill of waste (online) available from http://eur-lex.europa.eu/ (Accessed 02/02/2014)

[2]. EC-Europa.eu (2014a) The IPPC $\quad$ Directive $\quad(96 / 61 / \mathrm{EC}) \quad$ (online) available http://ec.europa.eu/environment/air/pollutants/stationary/ippc/summary.htm (Accessed 03/02/2014)

[3]. University of Sussex (no date) Albanians in Italy and Greece: a study in migration dynamics and social exclusion (online) available from https://www.sussex.ac.uk/webteam/gateway/file.php (Accessed 02/02/2014)

[4]. Bakas, I and Milios, L. (2013) Municipal Waste Management in Greece (online) available from www.eea.europa.eu/...municipalsolid-waste/greece-municipal-waste-management (Accessed 02/02/2014) 
[5]. United Nations Organisation (no date) Chapter IV Waste Management (online) available from www.un.org/.../greece/ (Accessed 02/02/2014)

[6]. Bosdogianni, A. (2007) Municipal Solid Waste Management in Greece - Legislation - Implementation Problems (online) available from http://waste.com.br/textos/062.pdf (Accessed 03/02/2014)

[7]. Eur-lex.europe.eu (1975) Council Directive 75/442/EEC of 15th July 1975 on waste (online) available from http://eurlex.europa.eu/ (Accessed 05/02/2014)

[8]. DEFRA (2011) The Hazardous Waste Directive (online) available from http://adlib.everysite.co.uk/adlib/defra/content.aspx (Accessed 05/02/2014)

[9]. PERKOUlidis, G., PAPAGEORGIOU, A., KARAGIANNIDIS, A. and KALOGIROU, S., 2010. Integrated assessment of a new Waste-to-Energy facility in Central Greece in the context of regional perspectives. Waste Management, 30(7), pp. 1395-1406.

[10]. Environment Agency (2013a) Waste data and information (online) available from http://www.environmentagency.gov.uk/research/library/data (Accessed 05/02/2014)

[11]. EC-Europa.eu (2014a) The IPPC Directive (96/61/EC) (online) available from http://ec.europa.eu/environment/air/pollutants/stationary/ippc/summary.htm (Accessed 03/02/2014)

[12]. DEFRA (2007) The Waste Framework Directive 1991/156/EEC (online) available from http://adlib.everysite.co.uk/adlib/defra/content (Accessed 03/02/2014)

[13]. EC-Europa.eu (2011b) Waste Incineration Directive (2000/76/EC) (online) available from http://europa.eu/legislation_summaries/environment/waste_management/128072_en.htm (Accessed 05/02/2014)

[14]. EC-Europa.ec (2011c) Packaging and Packaging Waste Directive (2004/12/EC) (online) available from http://europa.eu/legislation_summaries/environment/waste_management (Accessed 05/02/2014)

[15]. Penwell (2013a) Europe On The Right Track: Encouraging Prospects For End-Of-Life Tyre Management (online) available from http://www.waste-management-world.com/articles/print/volume-7/issue-7/features/europe-on-the-right-track-encouragingprospects-for-end-of-life-tyre-management.html Waste Management Word Magazine UK (Accessed 05/02/2014)

[16]. DEFRA (1994) The Hazardous Waste Directive (online) available from http://adlib.everysite.co.uk/adlib/defra/content.aspx (Accessed 06/02/2014)

[17]. EC-Europa.eu (2014e) Environmental Liability (online) available from http://ec.europa.eu/environment/legal/liability/ (Accessed 06/02/2014)

[18]. Environment Agency (2013b) International Waste Shipments (online) available from http://www.environmentagency.gov.uk/business/sectors/32447.aspx (Accessed 05/02/2014)

[19]. Eur-lex.europe.eu (1986) Council Directive (86/279/EEC) on the supervision and control within the European Community of the transfrontier shipment of hazardous waste (online) available from http://eur-lex.europa.eu/ (Accessed 06/02/2014)

[20]. UN Basel Convention (2011) BASEL CONVENTION Controlling transboundary movements of hazardous wastes and their disposal (online) available from http://www.basel.int/ (Accessed 06/02/2014)

[21]. European Union (2002) Directive 2002/96/EC OF THE EUROPEAN PARLIAMENT AND OF THE COUNCIL of 27 January 2003 on waste electrical and electronic equipment (WEEE) (online) available from http://eur-lex.europa.eu/LexUriServ (Accessed $05 / 02 / 2014)$

[22]. EC-Europa.eu (2014d) Recast of the WEEE Directive (online) available from http://ec.europa.eu/environment/waste/weee/index (Accessed 05/02/2014)

[23]. European Union (2006) Directive 2006/66/EC OF THE EUROPEAN PARLIAMENT AND OF THE COUNCIL of 6th September 2006 on batteries and accumulators and waste batteries and accumulators and repealing Directive 91/157/EEC (online) available from http://eur-lex.europa.eu/LexUriServ/LexUriServ (Accessed 05/02/2014)

[24]. Eur-lex.europe.eu (2008) Directive 2008/98/EC OF THE EUROPEAN PARLIAMENT AND OF THE COUNCIL OF 19TH NOVEMBER 2008 on waste and repealing certain Directives (online) available from http://eur-lex.europa.eu/LexUriServ (Accessed 06/02/2014)

[25]. EC-Europa.eu (2014a) The IPPC Directive (96/61/EC) (online) available from http://ec.europa.eu/environment/air/pollutants/stationary/ippc/summary.htm (Accessed 03/02/2014)

[26]. FAOLEX (no date) European Union Commission Decision 2000/532/EC replacing Decision 94/3/EC establishing a list of wastes pursuant to article 1 (a) of Council Directive 75/442/EEC on waste and Council Decision 94/904/EC establishing a list of hazardous waste pursuant to article 1 (4) of Council Directive 91/689/EEC on hazardous waste (online) available from http://faolex.fao.org/cgibin/faolex.exe(Accessed 06/02/2014)

[27]. Eur-lex.europe.eu (2001) 2001/573/EC: Council Decision of 23 July 2001 amending Commission Decision 2000/532/EC as regards the list of wastes (online) available from http://eur-lex.europa.eu/LexUriServ/LexUriServ. (Accessed 06/02/2014)

[28]. Eur - lex. europe.eu (1999) Council Directive 1999/31/EC of 26th April 1999 on the landfill of waste (online) available from http://eur-lex.europa.eu/ (Accessed 02/02/2014)

[29]. EC-Europa.eu (2006) Regulation (EC) NO 1013/2006 of the European Parliament and of the Council of 14th June 2006 on shipments of waste (online) available from http://eur-lex.europa.eu (Accessed 05/02/2014)

[30]. EC-Europa.eu (2014b) Review of the Environmental Impact Assessment (EIA) Directive (online) available from http://ec.europa.eu/environment/eia/review.htm (Accessed 05/02/2014)

[31]. Marpol Covention Greece (2002) Contribution Paper (audit experiences from MARPOL Convention audit) first rank judge (online) available from http://www.eurosaiwgea.org/Environmental\%20audits/Water/Documents/ (Accessed 06/02/2014)

[32]. ARVANITOYANNIS, I.S., TSERKEZOU, P. and CHOREFTAKI, S., 2008. 4 - Presentation and Comments on EU Legislation Related to Food Industries - Environment Interactions. In: I.S. ARVANITOYANNIS, ed, Waste Management for the Food Industries. Amsterdam: Academic Press, pp. 135-288

[33]. SANER, D., BLUMER, Y.B., LANG, D.J. and KOEHLER, A., 2011. Scenarios for the implementation of EU waste legislation at national level and their consequences for emissions from municipal waste incineration. Resources, Conservation and Recycling, 57(0), pp. 67-77.

[34]. PAPACHRISTOU, E., HADJIANGHELOU, H., DARAKAS, E., ALIVANIS, K., BELOU, A., IOANNIDOU, D., PARASKEVOPOULOU, E., POULIOS, K., KOUKOURIKOU, A., KOSMIDOU, N. and SORTIKOS, K., 2009. Perspectives for integrated municipal solid waste management in Thessaloniki, Greece. Waste Management, 29(3), pp. 1158-1162.

[35]. The Geographical Journal (2009) Implementing the Landfill Directive in Greece: problems, perspectives and lessons to be learned (online) available from Lasaridi, K (2009) (Ed) http://onlinelibrary.wiley.com/doi/10.1111/j.1475-4959.2009.00342.x/abstract (Accessed 03/02/2014)

[36]. GIDARAKOS, E., HAVAS, G. and NTZAMILIS, P., 2006. Municipal solid waste composition determination supporting the integrated solid waste management system in the island of Crete. Waste Management, 26(6), pp. 668-679. 
[37]. GIDARAKOS, E., HAVAS, G. and NTZAMILIS, P., 2006. Municipal solid waste composition determination supporting the integrated solid waste management system in the island of Crete. Waste Management, 26(6), pp. 668-679.

[38]. HMRC (no date) Landfill Tax (online) available from http://customs.hmrc.gov.uk/channelsPortalWebApp/channelsPortalWeb (Accessed 08/02/2014)

[39]. Lets recycle.com (2010) Defra withdraws funding from seven waste PFIs (online) available from http://www.letsrecycle.com/news/latest-news/councils/defra-withdraws-funding-from-seven-waste-pfis (Accessed 08/02/2014)

[40]. DEFRA (2008) Landfill allowance trading scheme (LATS) legislation and consultations (online) available from http://archive.defra.gov.uk/environment/waste/localauth/lats/legislation.htm (Accessed 08/02/2014)

[41]. Environment Agency (2014) Landfill Allowances and Trading Scheme (England) (online) available from http://www.environmentagency.gov.uk/business/topics/waste (Accessed 08/02/2014) 